\title{
Improper Physical Structure
}

National Cancer Institute

\section{Source}

National Cancer Institute. Improper Physical Structure. NCI Thesaurus. Code C92133.

Problems related to the incorrect or inadequate arrangement of the parts, components, elements, or materials. 